\title{
Still Joy: A Call for Wonder(ing) in Science Education as Anti-racist Vibrant Life-Living
}

\author{
Christie C. Byers
}

In this chapter I share a meta-assemblage research-creation (Manning, 2016): a researcher-created experimental exhibit of found poetic assemblages about wonder, joy, Black life, neurodiversity, love, science, and science education. The intention of this meta-assemblage research-creation is to explore the affective flows of the phenomenon of wonder, while also inviting consideration of how the multiple forces and co-components of the body(ies) assembled here move together in an uneasy and historically traceable tension. These comovements suggest how "traditional" science and school science education are not only complicit with, but also may be directly implicated as primary protagonists in the violent anti-Black racism and planet-wide suffering happening in our world today.

As an emerging science education researcher and long-time elementary science teacher in the United States, I have been thinking about and dwelling with the phenomenon of wonder for many years. I will share here an overview of some of my theorizing about the concept thus far as a means of providing

I I attach the (ing) to the base word "wonder" to denote one of the many nuanced dimensions of this complex phenomenon/affect: it assumes the form of both a noun (e.g., an object of wonder, a state of wonder, or the concept of wonder itself), and a verb-a dynamic process of wondering-movement that includes thinking-feeling through encounters, becoming aware of the extraordinary in-of the ordinary, connecting/integrating, exploring, imagining new possibilities, and creative improvisation.

C. C. Byers $(\bowtie)$

George Mason University, Fairfax, VA, USA 
context for engaging with the meta-assemblage that follows. Through a slow and transdisciplinary study, I have come to think-feel wonder(ing $)^{1}$ as a dynamic, multidimensional, multimodal, and somewhat sensitive and slippery affect (Byers, 2021); a common, ubiquitous, and catalytic force that works to open up possibilities and make felt potential in and through everyday events and encounters. Further, I have been wondering about the relationship of wonder with what psychologist Daniel Stern $(2004,2010)$ has termed "vitality affects"-affects we feel and sense in others, that permeate our everyday lives, and "are felt experiences of force, in movement - that have a temporal contour, and a sense of aliveness, of going somewhere" (Stern, 2010, p. 8). In a similar vein of thinking with movement and felt aliveness, biologist, philosopher, and biosemiotician Andreas Weber has developed the concept of enlivenment, a feeling of aliveness experienced in reciprocal relationships with other feeling beings in his books Enlivenment: A Poetics for the Anthropocene (2019), The Biology of Wonder: Aliveness, Feeling and the Metamorphosis of Science (2016), and Matter and Desire: An Erotic Ecology (2017). Rosi Braidotti, in her intellectually rigorous work mapping the proliferation of posthuman knowledges and scholarship, discusses an ethics of joy embedded in feminist posthuman thinking, related to vitality and increased capacities of bodies to affect in her many works, including Posthuman Knowledge (2019) and the co-edited volume Posthuman Glossary (2018, pp. 221-224). The concept of vitality affects has also been taken up by Felix Guattari as central to his ethico-aesthetic paradigm in his text, Chaosmosis (1995).

In coming to think of wonder(ing) as an opening-up and enlivening vitality affect, I have noticed that the phenomenon, as experienced, is never quite containable within human bodies or singular categories or disciplines. It resists enclosure, capture, and narrow or flat representation as it emerges in and through encounters (or perhaps it is always already there) and moves around and across "things" or "bodies" in a trans- (and transformational) manner. Wonder does move through and can be felt by human bodies, and even linger there for a little while, but this affect, like all affects, tends to behave more like a fleshy ghost (Stewart, 2007); sometimes appearing, moving through, between, and across bodies (Brennan, 2004), and then quickly vanishing again. Wonder(ing) has a habit of entering into and fleeting across encounters, popping up, or perhaps mediating the popping up, of little shocks of semi-awareness (Byers, 2021; Massumi, 2015). Wonder is also sometimes experienced as an intensity of feeling that slides across bodies more slowly, like a warm washing-over, registering as moments of clarity or awareness, deep presence, and a comforting sense of connectedness; the felt reality of relation (Massumi, 2002, p. 17, emphasis in original), with and across other bodies in the world (Di Paolantonio, 2018; Washington, 2019; Weber, 2016). The three main points that I am interested in focusing on here are that as an affect or intensity that is felt emerging in and through encounters, wonder(ing) (1) is always available (like an open invitation), (2) is always on the move (across), and (3) carries with it the powerful potential to move bodies (Ahmed, 
2015; Braidotti, 2019; Irigaray, 1993; Massumi, 2002). This capacity to move bodies might be expressed as increasing bodies' capacities to affect (Braidotti, 2019; Massumi, 2002, 2015; Spinoza, 2009). Wonder has indeed been linked with joyful exploration, imagination, creativity, and becoming inspired to take action (Glăveanu, 2020), and is increasingly being thought in association with the concept of human flourishing in education (Schinkel, 2020). Importantly, this increase in capacity to affect and association with human flourishing is always relational, and not individual; it involves co-created and co-moving intensities enabled through reciprocal relations with other bodies-regardless of whether these bodies are human or more-than-human matter (e.g., ideas, objects, animals, institutions, forces, organizations, plants, water, books, etc.) (Bazzul \& Kayumova, 2016; Braidotti, 2019; Haraway, 2016; Manning, 2016; Massumi, 2015; Weber, 2016).

The increase in capacity activated through wonder(ing) is quite palpableand is likely even measurable for those inclined toward measuring things and valuing things that are measurable. A few empirical studies have initiated efforts in this area (Hadzigeorgiou, 2012; Gilbert \& Byers, 2017; Girod et al., 2010; Girod \& Wong, 2002). In an empirical study I am currently grappling with writing up (Byers, 2021), for example, preservice elementary teachers who explicitly engaged with wonder(ing) in a science methods course through wonder journaling and digging into and sharing their wonders with one another science-fair style experienced the phenomenon as related to:

1. enthusiastic, motivated entry into learning through their interests and experiences;

2. feeling more "in tune" with self, "science," and one another;

3 . joyful engagement and a marked increase in "aliveness" or lively energy;

4. broadening views about knowledge/knowing and more comfort with uncertainty;

5. imagining and enacting possibilities of doing things differently; rethinking "structures" as "structured";

6 . perceiving the world as more open, more wonder-filled;

7. increased feelings of confidence and competence, or the capacity to affect;

8. a sense of wellbeing extending beyond the course into other areas of their lives.

The future teachers in the study exclaimed: "I am much more creative than I ever thought I was!" and "I learned I have so many ideas and they are not stupid!" and "I want to wonder more in my life!" in addition to dreaming up ways to promote and welcome wonder(ing) in their future teaching practices with elementary children.

Some of the data shared by these preservice teachers is included in the poetic meta-assemblage research-creation that follows. I juxtapose these with 
other forms of data that move with similar rhythms from scholarly texts, conversations, video recordings, photos, memos, etc. The exhibit, titled Still Joy, is an attempt to illustrate how wonder(ing), as an enlivening/enabling and life-affirming force/affect, is present, and has been moving, and continues to move in and through all areas of life-living, including troubled and racialized spaces. With respect to the wicked and ongoing problem of racism and anti-Black violence in the US, this assemblage attempts to provoke thought about how wonder(ing) carries with it the possibility, if intentionally attuned to, foregrounded, and allowed, of both calling out and troubling this trouble, while also (always) opening up new possibilities for vibrant and richly variegated life-living. Reflecting on this particular exhibit as it emerged through my experimental writing (Massumi, 2002) has me wonder(ing) whether foregrounding wonder in science education contexts may be a critical component of an anti-oppressive, life-affirming, plurality-celebrating mode of living science education otherwise.

Though I might have chosen to create this experimental, rhythmic collage of process philosophy and wonder thinking with any of the many rich areas of critical scholarship that work to interrogate and critique hegemonic violence wielded against marginalized "others" as my entry point, for this particular assemblage, I chose to focus on Black thought, highlighting especially the exact words of Black feminist, Black pedagogical, and Black philosophical and critical scholars. I make this intentional choice as a move toward taking on more responsible action in my scholarship - given the urgent need to directly address the current (and lengthy historical) circumstances of racial unrest and ongoing violence against Black people in the United States (Hattery \& Smith, 2018). My intended audience is mainly US teachers who teach science, elementary teachers especially, the majority of whom are white women like me. It is urgent that they/we recognize that doing things differently, by making decisive, ethical, and responsible moves in our classrooms is both possible and immediately necessary.

It is important to point out that this crying out for doing differently in science education is not an urging for yet another way of "helping" Black, Indigenous, Latinx, neurodiverse students, etc. through some kind of an assimilation project, where these "others" are deemed broken, behind, or less than and in need of being fixed, saved, and/or helped along by/through initiation into white Western structures of knowing and being. Rather, this work represents a call for caring for and valuing (and thus making space for) the rich and varied experiences, perspectives, ideas, modes of being/becoming, and diverse sense-making repertoires (Bang et al., 2017) that all children enter learning spaces with; an expansion of what it means to be "scientific"-and a pointing out that much of Western (white) science and traditional school science education is getting it wrong in the life-affirming department. Much (science) education today works to actively still, snuff out, and police any "out of bounds" movements. Attempts are made to tame the vibrant, reciprocal, relational life-living and joyfully active learning that is constantly emerging 
and trying to move and thrive in education spaces. A great deal of harm and suffering in the form of closing off capacity happens as a result of this stilling and policing. The argument here is that science learning, as a part of life itself in all of its ongoing emergence, diversity, playfulness, feeling, and vibrancy involves bursts of exuberance, difference-in-relation, creative and supernormal improvisations (Massumi, 2012), movements toward and through joy, and the forging of often unexpected and caring/reciprocal relations. If allowed, learning science could be and become so much more than the forced fragmentation, siloing, neutrality, stillness, hierarchical, distancing, and inert/static "rational" objectivity promoted today (Visvanathan, 2002; Weber, 2016, 2019; Whitehead, 1929). There is no view from nowhere (Haraway, 1988), no evolutionary hierarchy (Marks, 2017). I see this project as resonating with the marginal and minor yet ubiquitous transdisciplinary idea that vibrant, diverse, plurality of learning-as-life-living, and improvisational becoming-with others is always already moving and happening in and through encounters, through ongoing reciprocal processes of influx and efflux (Bennett, 2020), within locally situated ecological webs of relations (Braidotti, 2019; Cordova, 2007; Escobar, 2017; Haraway, 2016; Weber 2016, 2017, 2019). What I am attempting to amplify here is that wonder(ing) is a catalyst or primary force involved in a non-erasable life process: the ongoing ontogenesis of lively, movement-moving and becoming; movements that are always working with and gesturing toward what else is possible (Glăveanu, 2020; Manning, 2016; Massumi, 2002). What emerged for me (and continually moved me and moved through me) while creating this meta-assemblage is that policing and regulating Black life is intimately related to policing and regulating wonder. Both of these acts involve the violent disruption and attempted regulation and control of vibrant and precious life processes. What would happen if we valued and cared for these ongoing, relational emergences of difference and attempts at mutual flourishing? What if we moved with and followed these indeterminate felt elsewheres and otherwise possibilities (Vossoughi, 2021), instead of persistently enclosing, policing, and snuffing them out?

What I aim to make felt through this work is that making the time and space for wonder could be a relatively simple move to allow for these vital, deeply relational and emergent/divergent processes to do their work of (re)energizing bodies toward new and healthier/livelier modes of living, becoming, and creating together. Thriving. Not just surviving (Love, 2019). Notably, wonder(ing) is particularly powerful in that it registers as both critical and creative (Braidotti, 2019; Byers, 2021; Glăveanu, 2020). Welcoming wonder(ing) always carries with it the potential for a beginning again, for new beginnings; for a re-viewing (Glăveanu, 2020) and a re-newing. An opening-things-up that as Sara Ahmed (2015) points out "allows us to see the world as made," a world "that does not have to be" (p. 180), and "can be unmade as well as made. Wonder energizes the hope for transformation" (p. 181). Following this thinking, recognizing and welcoming 
wonder(ing) might allow educators and students to move together with (instead of constantly fighting against) the already-happening, relational, inclusive, affirmative, generative, joyful, and socially-just (science) education potential squirming around, putting out tendrils, and trying to thrive in the everyday; right there in plain sight.

Wonder already has one foot wedged into the proverbial science education door (well, perhaps just a winding tendril or a toe) through a couple of brief mentions in the Framework document underpinning the Next Generation Science Standards (NGSS), and appendix H of the NGSS document itself (see p. 28 of NRC, 2012 and p. 1 of appendix H, NGSS Lead States, 2013). Additionally, it gains support through scientists themselves who name wonder as central to their work and one of the greatest rewards they experience (Cantore, 1977; Carson, 1965; Hadzigeorgiou, 2014). The key for science educators is to allow for the time and space, and to be willing to create the necessary conditions (Byers, 2021) that would enable a full, multidimensional, and multimodal version of wonder(ing) to be welcomed and supported. As far as I can tell thus far in this wonder-tracking project, it is only a very narrow, known-facts, standards-based, and anemic version of wonder(ing) that is currently allowed in our current, impoverished version of (science) education (diAgnese, 2020; Visvanathan, 2002); something more akin to curiosity. Although curiosity is important, it represents a single, rather limited and superficial (Kingwell, 2000; Opdal, 2001) dimension within a pool of related concepts and phenomena that fall under the umbrella of wonder (Glăveanu, 2020). Even then, when curiosity, or a single-dimensional aspect of wonder(ing) is deemed allowable for children in (science) education contexts, it is too often with the intention that this phenomenon might be "captured" and/or (re)directed for exploitive, and/or predetermined, instrumental purposes, rather than for the opening up, exploratory, and trans-connective and enlivening possibilities that a fuller version of wonder(ing) might activate.

Importantly, these imaginative and connective possibilities catalyzed through wonder(ing) can never be fully anticipated in advance. This is perhaps one of the most challenging obstacles to foregrounding wonder in education today. Though the simple acts of slowing down, allowing and/or curating encounters, valuing diverse movements, and hesitating to regulate and police thought might promote wonder(ing), how do these kinds of moves align with the goals of education as they are conceptualized and enacted today? The common cultural approach in modern US schools is to speed up, standardize, fragment, and regulate knowledge for predetermined outcomes (diAgnese, 2020). In order to accomplish this, it is imperative to maintain authority and control, to "civilize" the perceived feral nature of children, perhaps most seriously affecting non-white and/or neurodivergent children (Shalaby, 2017). This regulating process results in the dampening of interest, (en)forced homogenization, and the bounding and swaddling of creative thought (Cant, 2017; Gilbert \& Gray, 2019). Notably, this control is often maintained 
through policing and punishing children's lively, moving bodies (Leafgren, 2016; Shalaby, 2017).

And now, finally, hoping the phenomenon of wonder(ing) has begun to take on a shape for readers through this overview, I turn to the metaassemblage research-creation itself. Although some portions of the work shared here might look and sometimes read like poetry, I am not quite a poet, and the work does not carry the trained artfulness and musicality of the kind of beautiful poetry those with poetic gifts are able to create. I am a (becoming) science education researcher who has been following wonder around and reading/thinking/tinkering with concepts that appear to resonate and relate with it. The forms presented here are researcher-data cocreated assemblages; an experimental exhibit of my thinking-in-progress put in motion along with the thinking of many others. This research-creation (Manning, 2016) is composed of and with snippets of found data, found texts, conversations, research memos, intuitive juxtapositions, photographs, and the following of creative impulses (Ulmer, 2018). The exact words I cut and pasted from other works into this moving collage are those that I felt resonating with the flow of the project. These works are cited in the footnotes. For copyright reasons, brief analysis notes of how I retroactively made sense of the inclusion of these words and works is included, though I do worry about the potential of these notes to foreclose thought and "capture" meaning-a move that does not align with spirit and movement of wonder(ing). During the actual event of the creation of this exhibit, the bits and pieces flowed together in ways that $\mathrm{I}$, as the researcher-composer, did not feel entirely in control of; or as Erin Manning (2016) might describe it: The material intuited its relational movement, and edged its way into form. These snippets of thought, or data scribbles, came together in an exhibit that (hopefully) works to make felt some of wonder(ing)'s meandering affects and effects, connections to contemporary social justice concerns, and movements toward more generative and affirmative modes of living out (science) education.

I also see this project as aligning with and gathering inspiration from Jasmine Ulmer's poetic call for critical qualitative inquiry is/as love (2017). Although this assemblage ends on a mournful note, this is the tragic reality of where we are in the United States today. Working for wonder, however, is, at its core, about making space for hope, for dreams, for play, for affirmative movement, for the joyful, vibrant, and deeply connected and mutually-flourishing existence that at some level we all know (feel) is possible.

$\underline{\text { Still Joy }}$

Insurgent Black life exceeds the bounds; it moves too much. ${ }^{2}$

${ }^{2}$ Manning (2016, p. 5). There are policed boundaries and norms for movement in US culture (including schools); Black life is perceived to exceed these, and thus is actively regulated/policed. 
My son likes to move and talk a lot, but his school required stillness, silence ${ }^{3}$

(it's like the monkeys are running the zoo)

A white teacher I know actually spoke these words, referring to a new school initiative to not punish or expel Black children quite as much.

I mean, it steals joy.

I think school steals joy-

it crushes wonder,

stifles imagination ${ }^{4}$

It happened with my son-

he's so curious about everything,

and yeah, he loves to move and talk. ${ }^{5}$

He's at home with me now, it's

been a gift for both of us-creating and

feeding curiosity together. We've really been co-learners,

and it's been joyful, absolutely full of wonder. ${ }^{6}$

I'm sorry, did you say steals joy, or.

stills joy?

My Southern/midwestern Twang

can be confusing-

but I was musing ...

I said steals, but stills works too. ${ }^{7}$

${ }^{3}$ Wendi Manuel-Scott, professor and scholar of race, gender, the African American experience, and the history of Black women in the Atlantic world, personal conversation. There are policed boundaries and norms for movement in US culture (including schools); Black life is perceived to exceed these, and thus is actively regulated/policed.

${ }^{4}$ Ibid. Wonder is thought here as a life process at the heart of ontogenesis/emergence of becoming: ongoing relational movements toward joy, imagination, creativity, and difference. There are policed boundaries and norms for movement in US culture (including schools); wonder exceeds these, and thus is actively regulated/policed.

${ }^{5}$ Ibid. There are policed boundaries and norms for movement in US culture (including schools); Black life is perceived to exceed these, and thus is actively regulated/policed.

${ }^{6}$ Ibid. Outside of the (bighly regulated/policed) school environment, wonder has been allowed to move around and flourish, with positive outcomes for both mother and child.

${ }^{7}$ Wendi Manuel-Scott, personal conversation. There are policed boundaries and norms for movement in US culture (including schools); wonder(ing), as movement, exceeds these, and thus is actively regulated. I/we connect school's stilling/stealing of wonder with stilling her (Black) son's movements back when he was in school. 
Steals. Stills.

"A rich science education has the potential to capture students' sense of wonder about the world and to spark their desire to continue learning about science throughout their lives." 8

\section{Capture?}

"If a child is to keep alive his inborn sense of wonder, he needs the companionship of at least one adult who can share it, rediscovering with him the joy, excitement, and mystery of the world we live in." 9

\section{Keep Alive?}

"I don't even know where to start. At what point did wondering become so difficult? It's almost as if that part of my brain is just locked away very deep, and I'm so structured and I'm so used to, 'no, this is how it's gonna be, so this is how you should do it." 10

\section{Locked Away?}

\section{So Intimidated about Teaching Science ${ }^{11}$}

Science is a source of a lot of anxiety

${ }^{8}$ National Research Council (2012, p. 28). Science education is poised to capture (and thus potentially exploit and regulate) the life process of wonder(ing) as expressed and experienced by children.

${ }^{9}$ Carson (1965, p. 55). Adults can help prevent the stilling/stealing of wonder (and thus keep wonder "alive") by attending to, encouraging, and sharing in children's wonder.

${ }^{10}$ Preservice elementary teacher, science methods course, 2017. Policing/regulating wonder might lead to wonder, as a life process, being forced to become "locked away" or hidden from view and replaced with the performed repetition of the normative order of things (receiving knowledge, not creating it), the traditional, acceptable mode of living/learning in schools.

${ }^{11}$ Byers (2021) Found Poetic Data Assemblage, 20 preservice elementary teachers, science methods course. All phrases from original data and (re)arranged by researcher, no new words added. Preservice teachers describe experiences with wonder(ing) being shut down over time (though recognizable in children-both the children they once were, and the children they are now observing as part of their teacher education placements in schools), as well as the regulating, intimidating nature of the kind of science education that they came to know through their past schooling experiences. Though these past experiences and memories have affected their views/confidence about teaching science, engaging with wonder (again) is opening up their thinking. 
for a lot of people,

So no, science has never been my strength.

Like back in school, I didn't get it super quickly so it wasn't something I was ever really confident in.

Because to me it's always been a very structured, like there's a black and white answer to everything that you do.

It wasn't even a thing really, it was like-you just filled out a packet. Like, 'this is the answer'-take it or leave it.

I remember being little, being in schoolI would get in trouble for getting off task and wondering about something. My mind was always racing, I always had a million questions, a million things running through my head.

Things would just like really grab my attention, like black holes, blood, life, God, deathjust like big things in general.

I would wonder about them, and ask questions, but no, that was not what we were talking about. Like "you're off task, you're off topic."

"That is definitely not in the curriculum."

We like shut down the "off topic" conversation. We just shut it down.

We squash the idea of wondering.

Kids are taught to just keep it to themselves.

I love watching children wonder about things they're curious little beings, constantly wondering little creatureslike their brains are so cool! It's like their whole body-and their whole mindI mean, they have wonders about everything! Everything is new to them!

But, they kind of learn to shut off that wonder. We just shut it down. We squish it. It's like we shut down all these 
like interests and fascinations, and it's like why?

I know that I am more passionate about things and I'm more interested in things when I like wonder about them and when I'm fascinated by them-

Why shouldn't we like, make that the standard?

How can we expect them to do well in school if they're not fascinated by anything?

If we don't allow them to be fascinated by anything?

And if we stifle wonder, they're not gonna even want to wonder any more.

Kids are like, all right, let's get through this, let's get to recess, or like let's get to the end of the day.

I think that's why I was so discouragedmy wonders were put on hold.

And yeah, I was really worried, so intimidated about teaching science.

\section{Science: A Fractured Pilgrimage ${ }^{12}$}

My favourite metaphor is of science as a journey a fractured pilgrimage that began as a search for man, nature and God; an attempt to be at home in the cosmos that became a homelessness. ${ }^{13}$

12 Byers (2021) Found Poetic Data Assemblage in Visvanathan (2002). Phrases (re)arranged by researcher. Minimal wording changes for flow and emphasis. This assemblage emphasizes Visvanathan's analysis from outside of Western science-detailing the "progress" of science as it became entangled with neoliberal capitalism and Cartesian dualisms, and the harm this collaboration has caused. As a solution, he suggests science might return to where it began: as embedded in (not separate from) life/nature; with wonder.

${ }^{13}$ Visvanathan (2002). Science as a discipline started out differently than what it later became. It began in a similar way to how a preservice teacher in the previous section described her own wonder(ing) as a child: as a search for answers to big questions; for finding a home/sense of belonging in the universe. It began with wonder, but later became a fragmenting process of separating self/other. 
The scientific self, an invention, perfected self as spectator; separated from the world, the object becomes a spectacle, a specimen. ${ }^{14}$

The constitution of self/object, self/ "other" begins through

this constitution of distance. ${ }^{15}$

Science, a hegemonized form of knowledge, reduced a whole series of "others" to lesser orders of being subject perpetually to the scientific gaze. ${ }^{16}$

Science as "neutral" is a lie; science creates its own 'microphysics of power' by determining discourses, by pre-empting the ways one thinks. ${ }^{17}$

And the link between science and market is essential; nature is seen as dead, a resource;

a mountain becomes a repository of ore. ${ }^{18}$

We must move from a glossary of distanced objectivityof "other" - to a language of relation and celebration to a dance of possibilities. 19

But first science needs to cry. ${ }^{20}$

${ }^{14}$ Visvanathan (2002). Science became a discipline that separates self/other, subject/object.

15 Ibid. Science became a discipline that separates self/other, subject/object.

${ }^{16}$ Ibid. Science has separated self/other in a hierarchical manner, and claimed power/hegemony.

17 Ibid. Science polices/regulates culture/society by claiming power and bounding discourses and thought through the guise of "neutrality."

18 Ibid. Science, as a discipline that separated self/other, subject/object also separated humans from nature, hierarchically, thus enabling the exploitation of ("dead, inert") nature for human purposes. Science is entangled with capitalism, applying market values to living beings and life processes.

${ }^{19}$ Ibid. A solution to the suffering caused by the hegemony of science may be through embracing relations and other possibilities beyond those currently narrowly defined, regulated, and policed by Western science.

${ }^{20} \mathrm{Ibid}$. Science might open up to the fullness of human experience, including the affective/emotive, beginning with a time of mourning for what it has become and the pain it has caused. 
Crying is essential-

for the earth and what science has become. ${ }^{21}$

When you cry, you care;

caring and crying may inaugurate

new social practices. ${ }^{22}$

There is more truth in crying

Than in any Cartesian meditation. ${ }^{23}$

And then science also needs laughter -

to not forget to be playful. ${ }^{24}$

Science should mimic nature in all its playfulness;

it is through play that ecology restores

by multiplying alternatives, lifestyles, life forms. ${ }^{25}$

And with this crying and laughing and playing,

science could begin again in wonder. ${ }^{26}$

Black people have always needed

the gift of wonder,

to be able to imagine, to dream

to believe in the impossible-

to imagine what might be $e^{27}$

and move toward that.

Movement-moving ${ }^{28}$

${ }^{21}$ Ibid. Science might open up to the fullness of human experience, including the affective/emotive, beginning with a time of mourning for the pain it has caused.

${ }^{22}$ Visvanathan (2002). Science might open up to the fullness of human experience: affect, emotion, care, empathy, etc. may be included as allowable scientific/social practices.

${ }^{23}$ Ibid. Crying (and other human modes of being) represent reality more accurately than Cartesian dualities that separate and hierarchize reason/emotion, dismissing the latter.

${ }^{24}$ Ibid. Opening up to the fullness of human experience would include laughter and play.

25 Ibid. Play is an ecological principle; a life process that includes exuberance and diversity. This process might be embraced and celebrated as a regular, allowable aspect of what life does; not regulated and policed.

${ }^{26}$ Ibid. It is through wonder that science began. Wondering is a primary process of lifeliving. Science might begin again in wonder in order to produce more life-affirming modes of living.

${ }^{27}$ Manuel-Scott, personal conversation. Black life, as regulated and policed life, has always needed wonder(ing) for its movement toward imagining what else is possible.

${ }^{28}$ Manning (2014). Life, thought here with the phenomenon of wonder catalyzing ontogenesis at the center, is always moving. Movement-moving is central to process philosophy. 
dream-dreaming

Our ancestors dreamed us up

and then bent reality to create us. ${ }^{29}$

Black women gardeners ${ }^{30}$

Black mothers tending gardens

deep, thoughtful women

where music was always on ${ }^{31}$

She's got to sing,

she can't help but sing! ${ }^{32}$

I know why the caged bird sings. ${ }^{33}$

If they ask you, tell them we were flying.

Freedom is (in) the invention of escape. ${ }^{34}$

The birds they sang

at the break of day

start again, I heard them say. 35

Black women mother gardeners

dreaming what might grow

in wide open fields,

and small brown plots-

dark rich soil full of

dream-drenched seeds.

Virtual possible/impossible

speculative fabulations 36

${ }^{29}$ Imarisha (2015). Black life, as regulated and policed life, needs wonder(ing) for its relation to dreaming, for activation of movement, for feeling and imagining the "what else is possible."

${ }^{30}$ Manuel-Scott, personal conversation. The recognition and affirmation of Black women for their lively, joyful wondering, life-affirming dreaming, hoping, and for planting seeds of possibility.

${ }^{31}$ Fred Moten interview (2018). The recognition and affirmation of Black women for their lively, joyful wondering, life-affirming dreaming, hoping, and for planting seeds of possibility.

32 Ibid. The recognition and affirmation of Black women for their lively, joyful wondering, life-affirming dreaming, hoping, and for planting seeds of possibility.

${ }^{33}$ Angelou (2009). Black women, despite facing regulation/policing/captivity are recognized and affirmed for their lively, joyful wondering, generative dreaming, singing, hoping, and planting seeds of possibility.

${ }^{34}$ Harney and Moten (2013). Connecting to birds/flight of the previous passage, wondering is viewed as related to/resonating with freedom/dreaming up escape from regulating structures.

35 Cohen (1984). Following the affective flow of bird metaphors from the lines before; bere resilience/persistence is added and woven in.

${ }^{36}$ Haraway (2016). Connecting wonder with dreaming, to joyful speculation of what else is possible. 
of dark/bright futures

spectral shimmers, Beloved ${ }^{37}$ fleshy ghosts ${ }^{38}$

sowing seeds, dispersing,

remembering,

intuiting.

The edgings into form of the material's intuition ${ }^{39}$

soil sweat blood Hughes poems dreams laughter

grandma Fitzgerald musical notes

playing bide and seek ${ }^{40}$

wings seeds land dance

all vibrant matter 41

Matter intuits its relational movement,

the capacity to think the more-than

as a memory of the future,

a time that makes its own way-

a time schism. ${ }^{42}$

A crack, a break

There is a crack, a crack in everything. ${ }^{43}$

Freedom is (in) the invention

of escape, stealing away in the confines,

in the form, of a break. ${ }^{44}$

These cracks, time schisms

are slower places, fugitive spaces

the there-here, then-now

of everyday encounters

${ }^{37}$ Morrison (1987). Wonder evokes spectral, the ineffable.

38 Stewart (2007). Wonder evokes spectral affects, the ineffable.

${ }^{39}$ Manning (2016). Manning's process philosophy includes the ontogenesis, or in-forming of material relations; wonder is thought here as being at the heart of this process.

${ }^{40}$ Fred Moten interview (2018). These words and affects contribute to the various entities/bodies/materials co-moving and becoming in-through the relational field of ontogenesis.

${ }^{41}$ Bennett (2010). Bennett's contribution here is her theorizing of the agency of matter.

42 Manning (2016). In the midst of events and encounters (where ontogenesis is occurring), there is felt a more-than, an excess, beyond linear or regulated/policed conceptions of time and space; this might be thought of as a crack, or a schism-a place for escape, or where new modes of life-living might emerge and thrive.

43 Cohen (1984). In the midst of events and encounters (where ontogenesis is occurring), there is always felt a more-than, an excess, beyond linear or regulated/policed conceptions of time and space; this might be thought of as a crack, or schism - a place for escape, or where new modes of life-living might emerge and thrive.

${ }^{44}$ Harney and Moten (2013). In the midst of events and encounters (where ontogenesis is occurring), there is always a more-than, an excess, beyond linear or regulated/policed conceptions of time and space; this might be thought of as a crack, or schism-a place for escape, or where new modes of life-living might emerge and thrive. 
the in-between here-where

time-space opens to the

more-than of what it seems.

The extraordinary in-of the ordinary. ${ }^{45}$

That nothing is quite what it seems in the movement-moving of an event suggests a kind of wondera wondering in movement, a wondering at the world directly. ${ }^{46}$

Wonder(ing) here is thought-felt as liminal-a liminal experience, ${ }^{47}$ the extraordinary in-of the ordinary. ${ }^{48}$ An ordinary affect. ${ }^{49}$ $A$ minor gesture ${ }^{50}$-gesturing, disorienting-orienting-reorienting, ${ }^{51}$ unsticking, sticking, 52 disassembling, assembling. ${ }^{53}$

A sort of shimmering apprehension on the threshold in between knowing and not knowing. ${ }^{54}$

A daydreamy schism in place-time

45 Glăveanu (2020). These schisms, or thresholds/openings toward other modes of being, are available in the ordinary/everyday.

${ }^{46}$ Manning $(2014$, pp. 165, 168). Manning connects movement and perception of the more-than in-through events with wondering at-with the world, unmediated. Wonder as a life-process, as catalyzing ontogenesis. This thought is developed from the thinking of many process-based philosophers (Massumi, Bergson, Simondon, Deleuze and Guattari, Whitehead, James, etc.).

47 Pearce and MacLure (2009, p. 254). Wonder (ing) is thought here as taking place at the edges of experience, in the in-between, the threshold spaces, or the previously mentioned cracks or time-schisms.

48 Glăveanu (2020). These schisms, or thresholds/openings gesturing toward other modes of being, are available in the ordinary/everyday.

${ }^{49}$ Stewart (2007). Wonder is common, ordinary; an everyday affect.

${ }^{50}$ Manning (2016). Analysis: these schisms, or thresholds/openings, are felt as (minor) gestures, in otherwise regulated/policed spaces (the major). They gesture toward other modes of being.

${ }^{51}$ Ahmed (2006). Ahmed discusses how wonder can help reorient what was previously oriented a different way: according to hegemony, power, structures that structure, regulate, police.

52 Ahmed (2010). Abmed theorizes regulated structures, norms, and affects as "sticky"thus wonder may help to open things back up, to help them get unstuck.

${ }^{53}$ Deleuze and Guattari (1987). There is a plurality/multiplicity of potential assemblages in a field of potentiality, or the plane of immanence making up the milieu of every event.

54 Pearce and MacLure (2009, p. 254). Wonder takes place at the edges of experience, in the in-between, threshold spaces, or time-schisms, troubling certainty and knowledge. 
other here-there

slowed down deep presence

feeling-thinking-moving

where the event is still welling 55

where aesthetic cognitive and spiritual modes

are simultaneously mobilized, ${ }^{56}$

where force has not yet turned to form,

here, in the midst-

there is potential for new diagrams

of life-living to be drawn. ${ }^{57}$

Space for rhizomatic ${ }^{58}$ sprouting,

vining tendrils branching winding bursting forth

writhing, thriving

$$
\text { (not just surviving) }
$$

\section{See Figure 9.1.}

We want to do more than survive!

We want our full humanity recognized with dignity! ${ }^{59}$

dancing pulsing laughing

fullness of life-living

the flux of liveliness coursing

through existence unlimited 60

It's about Black joy-

and always putting love

55 Manning (2016, p. 15). In the midst of events and encounters (where ontogenesis is occurring), there is always felt a more-than, an excess, beyond linear or regulated/policed conceptions of time and space; this might be thought of as a crack, or schism-a place for escape, or where new modes of life-living might emerge and thrive.

56 Pearce and MacLure (2009, p. 254). In the "midst" referred to in the previous line, there are primes mobilized across areas more traditionally thought of as separate (or that science has forced to be separate): spiritual, cognitive, aesthetic, realms, etc. Wonder is thought here as a connecting/synthesizing force, rather than one of fragmenting and separating these.

${ }^{57}$ Manning (2016, p. 15). In the midst of events and encounters (where ontogenesis is occurring), there is always felt a more-than, an excess, beyond linear or regulated/policed conceptions of time and space; this might be thought of as a crack, or schism-a place for escape, or where new modes of life-living might emerge and thrive.

${ }^{58}$ Deleuze and Guattari (1987). Rhizomatic movement is a non-hierarchical, non-linear form of movement.

${ }^{59}$ Love (2019). Black life is human life, and life itself (ontogenesis, desiring, thriving), and deserves/demands being treated as such; schooling for Black children needs to be about thriving, not just surviving.

${ }^{60}$ Manning (2016, citing Deleuze, 2005). The movement-moving (ontogenesis, emergence, liveliness) courses through existence eternally; it is always there and can be felt/attuned to (perhaps through wonder). 

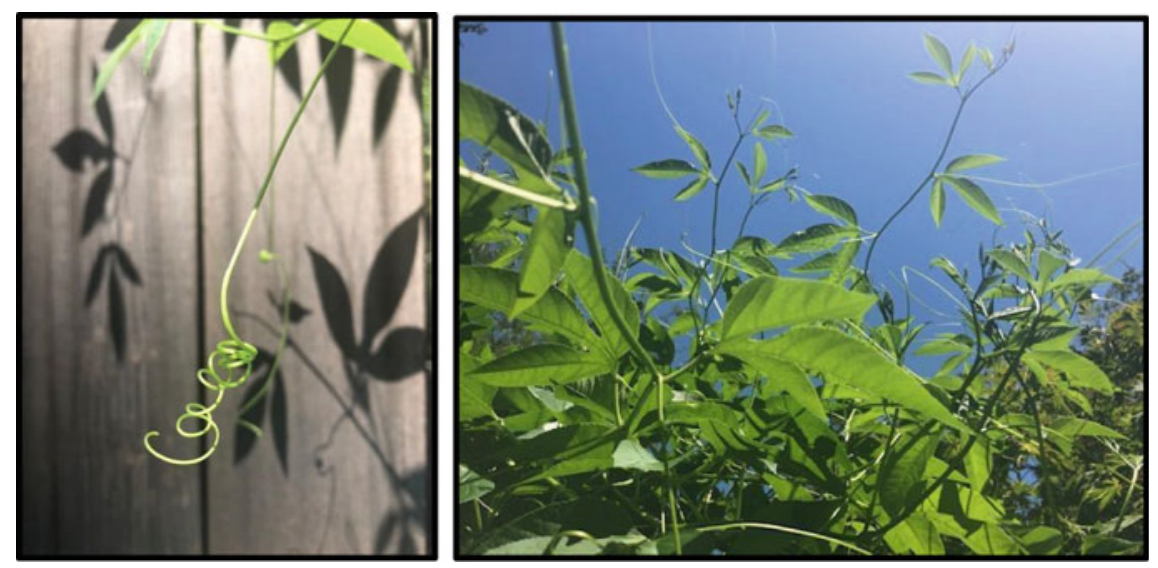

Fig. 9.1 Tendril-twisting, vine-vining: Wondering and thriving plant articulations of solidarity (Source Byers [2021], Takoma Park, MD)

at the center. ${ }^{61}$

bright buildings cracks, openings

that look like someone is ready

to love us in that space. ${ }^{62}$

Black joy, life-living

vibrating at edges-edging

Movement-moving,

edging into form. ${ }^{63}$

I don't need to disavow the notion

that black people have rhythm. ${ }^{64}$

(Look at them go! Look at them grow!)

${ }^{61}$ Love (2019). Life, wonder, joy, love are part of the same "alternative" or minor life processes (forced into minority; minoritized) described throughout the assemblage that need to be attuned to and centered. This is especially imperative for marginalized/racialized life. There are policed boundaries and norms for movement in US culture (including schools); Black life is perceived to exceed these, and thus is actively regulated.

${ }^{62}$ Love (2019). Life, wonder, joy, love are part of the same "alternative" or minor life processes described throughout the assemblage that need to be attuned to and centered. This is especially imperative for marginalized/racialized life. There are policed boundaries and norms for movement in US culture (including schools); Black life is perceived to exceed these, and thus is actively regulated.

${ }^{63}$ Manning (2014, 2016). Ontogenesis is an aspect of a process philosophy, creating diversity, new forms. Wonder is thought here to be at the heart of this process.

${ }^{64}$ Moten, as cited in Manning $(2016$, p. 5). There are policed boundaries and norms for movement in US culture (including schools); Black life is perceived to exceed these, and thus is actively regulated. 
Unpredictable, loud, sudden, bright, booming

(and often also) softly threading, sliding, silvery traces, windings crossings

shimmery snail trails ${ }^{65}$ of

looping relational enlivenment. 66

A lingering-tingling feeling

of aliveness-in-connection. ${ }^{67}$

Yes, this is this and that is that, ${ }^{68}$ and yet

what about and what if 69 this, and this, and this, and, and, and ...

(opening up to the trans-than, more-than, we teachers could ever have imagined, or ever planned, on our own)

And with such joy!

An ethics of joy! 70

Such dynamic supernormal improvisations. ${ }^{71}$

\section{Something Useful, Something Beautiful ${ }^{72}$}

You see something, you wonder about it, It ignites a fascination and it sparks you to then

$$
\text { do something ... }
$$

To, to, to, to

reach for something

connect to something life.

${ }^{65}$ Wallace and Byers (2018). There is no "essence" of life/subjectivities, including Black

${ }^{66}$ Weber (2019). Life, including Black life, moves toward joy, liveliness, aliveness-inconnection.

${ }^{67}$ Ibid. Life, including Black life, moves toward relation, joy, liveliness, aliveness-inconnection.

68 Byers (2021). Representations of stasis exist; but these are not all that are possible.

${ }^{69}$ Glăveanu (2020). Wonder is about the "what else is possible" always happening and available in plain sight.

${ }^{70}$ Braidotti (2019). Life moves toward joy; it is an ethical imperative to highlight and support this movement.

${ }^{71}$ Massumi (2012). Improvisation beyond the "norm"-movements toward difference is a life principle in a process-based philosophy.

72 Byers (2021) Found Poetic Data Assemblage, 20 preservice teachers, science methods course. Words and phrases from original data and (re)arranged by researcher, minimal words added for flow and emphasis. preservice teachers describe experiences with wonder (ing) as opening things up, involving movement/ fluidity, forging relationships, and inspiring joy, liveliness and new ideas/actions. 
make something

change something

I-we want to make something useful or beautiful!

With you and you and you-

(we all left feeling so good about each other)

it sparks you (us!)

into a kind of sudden awareness, like

there is so much more to this world

that we don't even know (yet)!

A spark! A pop! A flow! A flowing!

It all just flowed out.

(Like a stream of consciousness on the side of the page.)

It's fluid, beautifully fluid, and I love that!

I was pumped, to say the least!

It sparked me to come up with a question experiment design idea like to do actual science with a why and a reason behind it

For-with us, for-with people, for-with the planet

To, to, to, to

$$
\begin{aligned}
& \text { talk about } \\
& \text { write about } \\
& \text { create build say do } \\
& \qquad \text { something } \\
& \text { something useful } \\
& \text { something beautiful }
\end{aligned}
$$

Did you feel that?

Like a supernormal ${ }^{73}$ supernova.

A more expansive, inclusive, and ethical science.

${ }^{73}$ Massumi (2012). Improvisation beyond the "norm"-movements toward difference as a life principle. 
A broader sense of everything. ${ }^{74}$

A whole-ness of diverse part-ness.

A part-ness of diverse whole-ness.

A simplicity-complexity of wonder-wondering.

movement-moving 75

simplicity multiplicity plurality vibrancy

variegating vibrating aliveness.

Life-worth-living! A thriving even.

We want to do more than just survive! ${ }^{76}$

An embodied and embedded ecological ethics. ${ }^{77}$

An ethico-aesthetic paradigm. ${ }^{78}$

A mutual flourishing.

Black neurodiverse joyful insurgence,

is movement-moving. ${ }^{79}$

Insurgent Black life is neurodiverse

through and through. ${ }^{80}$

Somewhere along the line

Black flesh held the responsibility

of protecting generativity, 81

neurodiversity. 82

When you say Black life matters, you are saying that life matters, and when

${ }^{74}$ Byers (2021). A direct quotation from a preservice teacher; wonder as the opposite of narrowing.

${ }^{75}$ Manning (2014). This theorizing of wonder aligns with process philosophy.

${ }^{76}$ Love (2019). Black life is human life, and life itself (ontogenesis, desiring, thriving), and demands being treated as such; not just regulated and marked for (barely) surviving.

77 Braidotti (2019) and Weber (2016), mash-up. This theorizing of wonder(ing) aligns with posthumanist feminist theory and ecological life processes.

78 Guattari (1995). This theorizing of wonder aligns with Guattari's thinking about an alternative paradigm based on ethics, ecology, and aesthetics. An anti-fascist paradigm.

${ }^{79}$ Manning (2014). This theorizing of wonder aligns with process philosophy.

${ }^{80}$ Manning (2016, p. 5). Manning connects the neurodivergence movement (bonoring, celebrating a plurality of ways to be human, highlighting, especially, autistic perception attunement to a broad field of as-yet determined potential) with Black life, perceived as moving/being outside of the policed/regulated boundaries of life-living.

${ }^{81}$ Moten as cited in Manning (2016, p. 5). All of life is generative, improvisational, exuberant, always moving and moving toward difference, etc. Moten and Manning theorize how Black life came to represent this generativity and is thus is most violently policed.

${ }^{82}$ Manning (2016, p. 5). Manning makes the connection between neurodiversity and Black life. 
you say life matters, you are saying

Black life matters. ${ }^{83}$

Pressed tendril Black leg twitching

under taut white normopathy 84

scared stiff reflex muscle

$A$ threat to the order he represents

and that he is sworn to protect. ${ }^{85}$

Please $\operatorname{man}^{86}$

Stills. Joy, movement-moving

stilled.

Momma!

Momma I'm through! ${ }^{87}$

This is the threat:

Insurgent life ${ }^{88}$ as

movement-moving, bloom-blooming

tendrils-twisting, voice-booming

edge-edging, dance-dancing

wonder-winding, walk-walking,

path-pathing, dream-dreaming,

cry-crying, laugh-laughing,

wild-wilding

unfettered feral $^{89}$

life-living.

All of this.

This insurgent life cannot be properly regulated ${ }^{90}$

${ }^{83}$ Moten, as cited in Manning (2016, p. 5). All of life is generative, improvisational, exuberant, always moving and moving toward difference, etc. Somehow Black life came to represent this generativity and thus is most violently policed.

${ }^{84}$ Massumi (2014). The policing/regulating of norms is pathological (turning psychological/medicalizing phrasing on its head).

85 Moten, as cited in Manning (2016). There are policed boundaries and norms for movement in US culture (including schools); Black life is perceived to exceed these, and thus is actively regulated by the police, who are the border control. They are sworn to uphold these norms.

${ }^{86}$ George Floyd, May 25, 2020, words uttered while dying, his neck pinned under the knee of a white police officer in Minneapolis, Minnesota.

87 Ibid.

${ }^{88}$ Manning (2016, p. 5). Insurgent life is life moving outside of the regulated boundaries (Though insurgency, ontogenesis, improvisation, etc. is a regular, ecological life process).

${ }^{89}$ Gilbert and Gray (2019). Life is exuberant, moving, unpredictable, ever-changing.

${ }^{90}$ Manning (2016, p. 5). The policing of norms and boundaries becomes difficult, as these are regular, ongoing life processes. It is how life works. 
It is a profound threat to the already existing order of things. ${ }^{91}$

Capture wonder, still joy.

Insurgent life must be stilled.

Dispossessed, disposed of;

the only way to respond is to of get rid of them. ${ }^{92}$

Blackness, life-living, is life at the limit. ${ }^{93}$

Life is Black life. ${ }^{94}$

Anti-blackness is anti-life. ${ }^{95}$

Anti-life is anti-wonder.

Anti-wonder is anti-difference.

Anti-difference is anti-neurodiversity.

Anti-neurodiversity is anti-capacity.

Anti-capacity is anti-generativity.

Anti-dreaming

anti-movement

anti-joy

stilled joy

Anti-wonder is anti-blackness.

Anti-blackness is anti-flourishing.

Neurotypicality as founding identity politics

discounts discards, disposes of, stills all life

all generative force,

all unbounded, unpredictable,

rhythmic insurgent life 96

steals joy

${ }^{91}$ Moten, as cited in Manning (2016, p. 5). Life outside of the norms/boundaries is a threat and needs to be policed/regulated.

92 Thom (2016). The threat to hegemony (excessive movement beyond the bounds) must be eliminated.

${ }^{93}$ Manning (2016, p. 5). Black life, holding the responsibility for generativity, for living life at the limit, is profoundly threatening to the perceived order of things - to white supremacy, to normopathy.

${ }^{94}$ Moten, as cited in Manning (2016, p. 5). Black life is all life. Black life represents here the ontogenesis, generativity, joy, affirmation, connection, and movement processes at the beart of life itself.

95 Ibid. Black life is all life. Black life represents here the ontogenesis, generativity, joy, affirmation, connection, and movement processes at the heart of life itself.

${ }^{96}$ Manning (2016, p. 5). Analysis: Generative, unpredictably moving life (nonneurotypical life) is discounted; it must be snuffed out. This resonates with wonder(ing) being stilled, snuffed out. 
stills joy

stills.

We need to ask:

Can there still be joy?

Is there joy still?

In the stilling of Black life, in the stilling of insurgent life, in the stilling of generativity, in the stilling of neurodiversity, in the stilling of feeling, in the stilling (and dis-stilling) and the placing of a leg on the neck of a breathing, (and now nearly breathless) planet-

Is there still joy?

\section{REFERENCES}

Ahmed, S. (2006). Queer phenomenology: Orientations, objects, others. Duke University Press.

Ahmed, S. (2010). Happy objects. In M. Gregg \& G. J. Seigworth (Eds.), The affect theory reader (pp. 29-51). Duke University Press.

Ahmed, S. (2015). The cultural politics of emotion. Routledge.

Angelou, M. (2009). I know why the caged bird sings. Ballantine Books. (Original book published 1969.)

Bang. M., Brown, B., Barton, A. C., Rosebery, A. \& Warren, B. (2017). Toward more equitable learning in science: Expanding relationships among students, teachers and science practices. In C. V. Scharz, C. Passmore, \& B. J. Reiser (Eds.), Helping students make sense of the world using next generation science and engineering practices (pp. 33-58). NSTA Press.

Bazzul, J., \& Kayumova, S. (2016). Toward a social ontology for science education: Introducing Deleuze and Guattari's assemblages. Educational Philosophy and Theory, $48(3), 284-299$.

Bennett, J. (2010). Vibrant matter: A political ecology of things. Duke University Press. Bennett, J. (2020). Influx and efflux: Writing up with Walt Whitman. Duke University Press.

Braidotti, R. (2019). Posthuman knowledge. Polity Press.

Braidotti, R., \& Hlavajova, M. (Eds.). (2018) Posthuman glossary. Bloomsbury Academic.

Brennan, T. (2004). The transmission of affect. Cornell University Press.

Byers, C. C. (2021). "A broader sense of everything": The affects/effects of wonder(ing) in a science methods course (Unpublished manuscript). College of Education and Human Development, George Mason University. 
Cant, A. (2017). Unswaddling pedagogy. Canadian ISBN Service.

Cantore, E. (1977). Scientific man: The humanist significance of science. ISH Publications.

Carson, R. (1965). The sense of wonder. Harper and Row.

Cohen. L. (1984). Anthem [Song]. On The future [Album]. Columbia Records.

Cordova, V. (2007). How it is: The Native American philosophy of V. F. Cordova. University of Arizona Press.

Critical Resistance. (n.d.). Do black lives matter? Robin D. G. Kelley and Fred Moten in conversation. [Video file]. https://vimeo.com/116111740.

diAgnese, V. (2020). Contrasting the neoliberal educational agenda: Wonder reconsidered. In A. Schinkel (Ed.), Wonder, education, and human flourishing: Theoretical, empirical, and practical perspectives (pp. 23-39). VU University Press.

Deleuze, G. (2005). Pure immanence: Essays on life. Zone Books.

Deleuze, G., \& Guattari, F. (1987). A thousand plateaus: Capitalism and schizophrenia (B. Massumi, Trans.) University of Minnesota Press. (Original work published 1980).

Di Paolantonio, M. (2018). Wonder, guarding against thoughtlessness in education. Studies in Philosophy and Education, 38, 213-228. https://doi.org/10.1007/s11 217-018-9626-3.

Escobar, A. (2017). Designs for the pluriverse: Radical interdependence, autonomy, and the making of worlds. Duke University Press.

Gilbert, A., \& Byers, C. C. (2017). Wonder as a tool to engage preservice elementary teachers in science learning and teaching. Science Education, 101(6), 907-928.

Gilbert, A., \& Gray, E. (2019). Wonder in the science classroom. In S. Fifield \& W. Letts (Eds.), STEM of desire: Queer theories in science education (pp. 109-123). Sense Publishing.

Girod, M., Twyman, T., \& Wojcikiewicz, S. (2010). Teaching and learning science for transformative, aesthetic experience. Journal of Science Teacher Education, 21, 801-824.

Girod, M., \& Wong, D. (2002). An aesthetic (Deweyian) perspective on science learning: Case studies of three fourth graders. The Elementary School Journal, $102(3), 199-224$.

Glăveanu, V. P. (2020). Wonder: The extraordinary power of an ordinary experience. Bloomsbury Academic.

Guattari, F. (1995). Chaosmosis: An ethico-aesthetic paradigm. Indiana University Press.

Hadzigeorgiou, Y. (2012). Fostering a sense of wonder in the science classroom. Research in Science Education, 42(5), 985-1005.

Hadzigeorgiou, Y. (2014). Reclaiming the value of wonder in science education. In K. Egan, A. Cant, \& G. Judson (Eds.), Wonder-full education: The centrality of wonder in teaching, and learning across the curriculum (pp. 40-65). Routledge.

Haraway, D. (1988). Situated knowledges: The science question in feminism and the privilege of partial perspective. Feminist Studies, 14(3), 575-599.

Haraway, D. (2016). Staying with the trouble: Making kin in the Chthulucene. Duke University Press.

Harney, S., \& Moten, F. (2013). The undercommons: Fugitive planning and black study. Minor Compositions.

Hattery, A., \& Smith, E. (2018). Policing black bodies: How black lives are surveilled and how to work for change. Rowman \& Littlefield. 
Imarisha, W. (2015). Introduction. In W. Imarisha \& a. m. brown (Eds.), Octavia's brood: Science fiction stories from social justice movements (pp. 3-6). AK Press.

Irigaray, L. (1993). An ethics of sexual difference (C. Burke and G. C. Gill, Trans.). The Anthlone Press. (Original work published 1984).

John Hope Franklin Center at Duke University. (2018, November 5). Left of black with Fred Moten [Video file]. https://www.youtube.com/watch?v=fFTkoZTFdlk.

Kingwell, M. (2000). Husserl's sense of wonder. The Philosophical Forum, 31(1), 85107. https://doi.org/10.1111/0031-806X.00029.

Leafgren, S. (2016). Reuben's fall: A rhizomatic analysis of disobedience in kindergarten. Routledge.

Love, B. (2019). We want to do more than just survive: Abolitionist teaching and the pursuit of educational freedom. Beacon Press.

Manning, E. (2014). Wondering the world directly-or how movement outruns the subject. Body \& Society, 20(3\&4), 162-188.

Manning, E. (2016). The minor gesture. Duke University Press.

Marks, J. (2017). Is science racist? Polity Press.

Massumi, B. (2002). Parables for the virtual: Movement, affect, sensation. Duke University Press.

Massumi, B. (2012, May 3-5). Animality and abstraction. [Plenary session]. The Nonhuman Turn, Milwaukee, WI. https://www.youtube.com/watch?v=YkF9vh sraxE.

Massumi, B. (2014). What animals teach us about politics. Duke University Press.

Massumi, B. (2015). The politics of affect. Polity Press.

Morrison, T. (1987). Beloved. Alfred A. Knopf.

National Research Council. (2012). A framework for K-12 science education: Practices, crosscutting concepts, and core ideas. The National Academies Press. https://doi.org/ $10.17226 / 13165$.

NGSS Lead States. (2013). Next generation science standards: For states, by states. The National Academies Press.

Opdal, M. (2001). Curiosity, wonder and education seen as perspective development. Studies in Philosophy and Education, 20, 331-344.

Pearce, C., \& MacLure, M. (2009). The wonder of method. International Journal of Research and Method in Education, 32(3), 249-265.

Schinkel, A. (Ed.). (2020). Wonder, education, and human flourishing: Theoretical, empirical, and practical perspectives. VU University Press.

Shalaby, C. (2017). Troublemakers: Lessons in freedom from young children at school. The New Press.

Spinoza, B. (2009). The ethics. Wilder.

Stern, D. (2004). The present moment in psychotherapy and everyday life. W.W. Norton and Company.

Stern, D. (2010). Forms of vitality: Exploring dynamic experience in psychology and the arts. Oxford University Press.

Stewart, K. (2007). Ordinary affects. Duke University Press.

Thom, K. C. (2016, November 27). 8 steps toward building indispensability (instead of disposability) culture. Everyday feminism. https://everydayfeminism.com/2016/ 11/indispensability-vs-disposability-culture/.

Ulmer, J. B. (2017). Critical qualitative inquiry is/as love. Qualitative Inquiry, 23(7), 543-544. 
Ulmer, J. B. (2018). Composing techniques: Choreographing a postqualitative writing practice. Qualitative Inquiry, 24(9), 728-736.

Visvanathan, C. S. (2002). Between pilgrimage and citizenship, the possibilities of self-restraint in science. In C. A. Odora Hoppers (Ed.), Indigenous knowledge and the integration of knowledge systems: Towards a philosophy of articulation (pp. 39-52). New Africa (Pty) Ltd.

Vossoughi, S. (2021, April 8-12). Elsewhere worlds, poetics, and the science of human learning: a reflection in four verses [Jan Hawkins Lecture]. AERA 2021 Virtual Annual Meeting.

Wallace, M. F. G., \& Byers, C. C. (2018). Duo-currere: Nomads in dialogue (re)searching for possibilities of permeability in elementary science teacher education. Currere Exchange Journal, 2(1), 59-68.

Washington, H. (2019). A sense of wonder towards nature: Healing the planet through belonging. Routledge.

Weber, A. (2016). The biology of wonder: Aliveness, feeling, and the metamorphosis of science. New Society Press.

Weber, A. (2017). Matter and desire: An erotic ecology. Chelsea Green Publishing. Weber, A. (2019). Enlivenment: Toward a poetics for the Anthropocene. MIT Press. Whitehead, A. N. (1929). The aims of education. Macmillan.

Open Access This chapter is licensed under the terms of the Creative Commons Attribution 4.0 International License (http://creativecommons.org/licenses/by/4.0/), which permits use, sharing, adaptation, distribution and reproduction in any medium or format, as long as you give appropriate credit to the original author(s) and the source, provide a link to the Creative Commons license and indicate if changes were made.

The images or other third party material in this chapter are included in the chapter's Creative Commons license, unless indicated otherwise in a credit line to the material. If material is not included in the chapter's Creative Commons license and your intended use is not permitted by statutory regulation or exceeds the permitted use, you will need to obtain permission directly from the copyright holder. 